\title{
Research regarding the electrification risk of materials, technical equipment and appearance of electrostatic discharges in the presence of explosive atmospheres
}

\author{
Florin Adrian Păun *, Mihaela Părăian, Mihai Cătălin Popa, and Dan Gabor \\ ${ }^{1}$ The National Institute of Research and Development for Safety in Mines and Explosion Protection, \\ 32-34 G-ral Vasile Milea, Petroșani, România
}

\begin{abstract}
The electrification process of the materials and technical equipment's, especially the external parts of them, frequently occur during their use, being sometimes an intrinsic process, such as for example flowing of a flammable liquid through a pipe.

The electrification process of materials and technical equipment's is responsible for generating, through specific mechanisms, significant quantities of electrostatic charges.

The presence of electrostatic charges on materials and technical equipment's, used in areas with explosive atmospheres as a result of the electrification process can lead to electrostatic discharges occurrence, which in the presence of an explosive atmosphere may cause an explosion and/or fire.

The purpose of the paper is the analyze of essential safety and health requirements applicable to technical equipment's and materials intended for use in areas with explosive atmospheres in order to identify and establish technical and organizational measures, by their application can eliminate the risk of electrification, the occurrence of electrostatic discharges and consequently the risk of an explosion and/or fire may be reduced.
\end{abstract}

\section{Introduction}

Materials and equipment's, during their use, are generally subjected to the electrification process, which results in the formation and accumulation of electrostatic charges. The formation and accumulation of electrostatic charges occurs as a result of electrification mechanisms.

One of the electrification mechanisms that lead to the appearance and formation of electrostatic charges is contact electrification. If two materials of different nature are brought into contact and then separated, they will carry electrostatic charges equal size and opposite signs.

\footnotetext{
* Corresponding author: florin.paun@insemex.ro
} 
The contact electrification at materials and technical equipment's occurs when friction exist. The friction, which is a particular case of electrification contact, is responsible in most situations on major electrification that lead to special risks in the presence of an explosive atmosphere or other sensitive safety devices.

To the electrification degree of materials and equipment's by friction, also contributes a number of factors such as: the nature of the materials, the contact surface, the contact pressure, the relative displacement speed, the friction frequency/duration and the environmental conditions.

Also, another component of the electrification mechanism is induction electrification, in which case the conductive materials may be charged with electrostatic charges from another loaded object from vicinity. Materials can also receive charges by transferring either directly from other objects or through influence by a non-self-sustained discharge.

The electrification of materials and technical equipment's through the two abovementioned mechanisms present a particular importance when there are used in areas with potentially explosive atmospheres due to the risk of explosion and/or fire generated by the occurrence of electrostatic discharges in the presence of an explosive atmosphere.

The risk of fire and explosions due to the initiation of explosive atmospheres by electrostatic discharge requires the application of measures that minimize their effects on the safety and health of workers and other persons.

In this context, it is very important to identify and establish those measures that prevent occurring of these risks in order to ensure the highest possible level of safety and health at work.

One of the necessary measures is the use of suitable materials and technical equipment's, adequate for the intended use area, which meets the essential health and safety requirements specific to environments with explosion danger, so as to avoid the possibility of generating electrical, mechanical, or other nature sources.

Generally, in the industrial spaces where combustible/flammable substances are processed, explosive mixtures of gases, vapors, mists or dust and air may occur under normal working conditions due to processes or accidental leakages.

Generally speaking, to reduce the risk of explosions in industrial spaces with potentially explosive atmospheres, materials and technical equipment's must be used, specially designed for potentially explosive atmospheres that do not produce or constitute sources of energy that could initiate an explosion.

It follows that the materials and technical equipment's used in the Ex areas must meet the essential safety requirements regarding to the explosions hazard by preventing intrinsic sources of ignition of the explosive atmosphere, such as, for example, and those of electrostatic nature.

\section{The danger generated by electrostatic discharges in the presence of explosive atmospheres}

During the operations a person performs and his movement, his electrification potential can reach $2,5 \div 3 \mathrm{kV}$, and the energy accumulated in these cases reaches $5 \times 10^{-4} \mathrm{~J}$, which exceeds the minimum value of the ignition energy of many flammable substances.

In most industrial situations, electrostatic charges are transferred to persons as a result of their proximity to the processes that generate such charges. Regardless of the method or mechanism by which these charges are accumulate, the issue that is being raised and remains in question is the accumulation and subsequent discharging of these charges.

There is a possibility that the flammable atmosphere and electrostatic discharges to coexist without initiation; this situation being possible due to the fact that the discharge 
energy is small enough so that it is not able to initiate the atmosphere. However, if the discharging energy increases, a threshold is reached from which discharges become incendiary either partially or entirely, and thus can initiate a flammable mixture [1].

This energy threshold referred to is nothing other than the minimum ignition energy (MIE) that is usually expressed in $\mathrm{mJ}$.

Propagation brush discharges that are limited as discharge energy compared to other types of electrostatic discharges present a risk of ignition in the presence of gases and vapors from hydrocarbons and their possible hybrids, but it is unlikely to ignite dust clouds. The ignition of industrial dust through propagation brush discharges still remains to be demonstrated even if some fine dry powders may have a minimum ignition energy of less than $1 \mathrm{~mJ}$.

As a result of the researches carried out, it was found, for example, that when removing outer garments made of synthetic fibers by persons wearing such garments, they electrified at $15 \mathrm{kV}$ under a relative humidity of $50 \%$. It has also been found that the shaking of the dry coal dust on the clothing has a potential of up to $2 \mathrm{kV}$.

Both clean and dirty clothing (rock powder, coal dust) can electrify, but the accumulated electrostatic potential is still greater in the case of the dirty one. The ability to electrify of clothing after washing and drying is the same. No electrifying differences were observed between the clothing spotted with rock dust and coal dust. However, electrification of clothing occurs slower at removing rock powder than coal dust.

It can be observed that the electrification of persons and individual protective means under certain conditions may be dangerous in terms of ignition of explosive atmospheres.

The danger of explosive atmospheres ignition is also present in the use of technical equipment's as a result of the occurrence and generation of ignition sources, among which static electricity and electrostatic discharges which results from their non-metallic parts or cases [1].

Therefore, in order to avoid and/or reduce to an acceptable level the risk of explosion, the technical equipment's must meet the essential safety and health requirements of ATEX Directive 2014/34/EU [2].

For this purpose, in ATEX Directive 2014/34/EU, groups and categories of equipment intended for use in potentially explosive atmospheres are defined, table 1 and 2 [2, 3].

Table 1. Group and minimum ignition energy for a series of representative substances

\begin{tabular}{|c|c|c|}
\hline Group & $\begin{array}{c}\text { Dangerous } \\
\text { substance }\end{array}$ & $\begin{array}{c}\text { Minimum } \\
\text { ignition energy } \\
{[\boldsymbol{\mu} \boldsymbol{J}]}\end{array}$ \\
\hline IIA & $\begin{array}{c}\text { methane, } \\
\text { propane }\end{array}$ & 260 \\
\hline IIB & ethylene & 95 \\
\hline IIC & $\begin{array}{c}\text { hydrogen, } \\
\text { acetylene }\end{array}$ & 18 \\
\hline
\end{tabular}

Table 2. The relationship between the explosion group, equipment category and the level of protection

\begin{tabular}{|c|c|c|}
\hline Explosion group & Equipment category & EPL \\
\hline \multirow{2}{*}{ Group I } & \multicolumn{2}{|c|}{$\mathrm{M} 1$} \\
\cline { 2 - 3 } & \multicolumn{2}{|c|}{$\mathrm{M} 2$} \\
\hline \multirow{2}{*}{ Group II } & 2 & $\mathrm{Ga}$ \\
\cline { 2 - 3 } & 3 & $\mathrm{~Gb}$ \\
\cline { 2 - 3 } & 2 & $\mathrm{Gc}$ \\
\hline
\end{tabular}


Generally, the technical equipment's is part of a technological installation to which it's added other components such as electrical cables, tanks, pipes, conveyor belts, transmission belts, etc.

As a consequence, the risk of explosive atmospheres initiating may also occur at the technological installations due to the electrification of the components (pipelines, conveyor belts, transmission belts, etc.) to high potential and subsequent discharge of them by static electricity discharges.

Prevention of static electricity in industrial plants involves the use of technical equipment's and material adequate from the point of view of the risks arising from the presence of electrostatic charges, to which it's added the application of measures and general principles of protection.

For example, one of the protective measures referred to is the earthing of metal tanks, tank structures and any other isolated metallic object associated either intentionally or accidentally in the handling operations of flammable liquids.

In the absence of earthing and insulation them against the earth due to loading mechanisms, a high electrostatic potential would be generated. That is why all the conductive parts of a liquid handling system must be properly earthed to the ground.

The limitation of charge generation in such systems can be ensured by controlling the relevant process parameters (liquid flow rate, pipe diameter, liquid conductivity).

The belts used for power transmission or conveyor belts for solid materials can generate a considerable amount of charges and can become a danger of ignition due to continued separation of the contact surfaces (mainly a drive shaft and a belt).

The amount of charge gained depends on the material of the conveyor belt as well as the materials of the drive shaft and the rollers and increases with the speed and tension of the belt and the width of the contact area.

The accumulated charges of the conveyor belt can be safely dissipated only to the ground by the earth-connected conductive rollers if the conveyor belt is sufficiently dissipative. It can't be expected that a conductive or dissipative conveyor belt to take over the charges accumulated by the transported insulating product.

Grease layers or residues on conveyor belt can increase the conveyor belt load capacity and also its strength, and this can increase the load hazard. The drive belts are V-shaped belts and flat belts which act rotating parts or machines.

The amount of charges accumulated by the belt due to the continuous separation of the contact surfaces depends on the belt material and rollers and increases with the speed, belt tension and width of the contact surfaces.

\section{Reducing the ignition danger of explosive atmospheres by electrostatic discharges}

Reducing the ignition danger of explosive atmospheres and consequently producing an explosion and/or fire may be carried out by complying with the essential health and safety requirements applicable to materials and technical equipment's used in areas with danger of potentially explosive atmospheres.

With regard to the prevention of the explosion and/or fire danger, a series of protective measures may be applied, as appropriate, such as: earthing, the use of appropriate materials, antistatic treatment of materials, especially those used for the manufacture of protective clothing, choosing the adequate form of construction, avoiding dangerous friction by limiting the velocity of the belt movement or the flow rate through pipes, high humidity, use of charges neutralizers [4].

In the case of technical equipment's used in areas with flammable gases, vapors and/or mists, the danger of ignition due to electrostatic charges can be avoided by [5]: 
a) the appropriate choice of material so that the surface resistance corresponds to the limits specified below:

- $10^{9} \Omega$ measured at (50 \pm 5$) \%$ relative humidity; or

$-10^{11} \Omega$ measured at $(30 \pm 5) \%$ relative humidity

b) limiting the surface area of the non-metallic parts of the carcases as shown in the Table 3

c) limiting the nonmetallic layer bound to a conductive surface. The thickness of the non-metallic layer shall not exceed the values given in Table 4 or the breakdown voltage shall be $\leq 4 \mathrm{kV}$ (measured on the thickness of the insulating material according to the method described in IEC 60243-1);

d) providing a conductive coating.

e) marking the equipment with " $\mathrm{X}$ " for fixed plants where the installation is intended to minimize the risk of electrostatic discharges.

Table 3. Limiting surface areas

\begin{tabular}{|c|c|c|c|c|}
\hline \multicolumn{5}{|c|}{$\begin{array}{c}\text { Maximum surface area } \\
\mathbf{m m}^{\mathbf{2}}\end{array}$} \\
\hline \multirow{3}{*}{$\begin{array}{c}\text { Equipment } \\
\text { group I }\end{array}$} & $\begin{array}{c}\text { Equipment group II } \\
\text { Protection level of } \\
\text { equipment }\end{array}$ & Group IIA & Group IIB & Group IIC \\
\hline \multirow{3}{*}{10000} & EPL Ga & 5000 & 2500 & 400 \\
\cline { 2 - 5 } & EPL Gb & 10000 & 10000 & 2000 \\
\cline { 2 - 5 } & EPL Gc & 10000 & 10000 & 2000 \\
\hline
\end{tabular}

Table 4. Limiting the thickness of the non-metallic layer

\begin{tabular}{|c|c|c|c|c|}
\hline \multicolumn{5}{|c|}{$\begin{array}{c}\text { Maximum thickness } \\
\text { mm }\end{array}$} \\
\hline \multirow{2}{*}{$\begin{array}{c}\text { Equipment } \\
\text { group I }\end{array}$} & $\begin{array}{c}\text { Pquipment group II } \\
\text { Protection level of } \\
\text { equipment }\end{array}$ & Group IIA & Group IIB & Group IIC \\
\hline \multirow{3}{*}{2} & EPL Ga & 2 & 2 & 0,2 \\
\cline { 2 - 5 } & EPL Gb & 2 & 2 & 0,2 \\
\cline { 2 - 5 } & EPL Gc & 2 & 2 & 0,2 \\
\hline
\end{tabular}

In the case of transmission belts used for drive or conveyor belts for solid materials, the safety requirements refer to their antistatic properties and to surface electrical resistance. The material of a conveyor belt is considered to be dissipative if it meets the requirements of Table 5 with additional measures necessary according to the classification of hazardous areas [6]. 
Table 5. Requirements for conveyor belts

\begin{tabular}{|c|c|c|c|c|c|c|c|c|c|}
\hline \multirow{2}{*}{$\begin{array}{c}\text { Belt } \\
\text { velocity }\end{array}$} & \multirow{2}{*}{$\begin{array}{c}\text { Dissipative } \\
\text { criteria }\end{array}$} & \multirow[t]{2}{*}{ Zone 0} & \multicolumn{2}{|c|}{ Zone 1} & \multirow[t]{2}{*}{ Zone 2} & \multicolumn{2}{|c|}{ Zone 20} & \multirow[t]{2}{*}{ Zone 21} & \multirow[t]{2}{*}{ Zone 22} \\
\hline & & & IIC & IIA \& IIB & & $\begin{array}{c}\text { MIE } \\
<10 \text { mJ }\end{array}$ & \begin{tabular}{|c|}
$\mathrm{MIE}$ \\
$>10 \mathrm{~mJ}$
\end{tabular} & & \\
\hline $\begin{array}{c}0-30 \\
\mathrm{~m} / \mathrm{s}\end{array}$ & $\begin{array}{c}\text { Surface } \\
\text { resistances } \\
<3 \times 10^{8} \Omega \\
\text { or resistance } \\
\text { between } \\
\text { outer } \\
\text { surfaces } \\
<10^{9} \Omega\end{array}$ & $\begin{array}{r}\text { Dissil } \\
\text { conv } \\
\text { belt } \\
\text { cond } \\
\text { roll } \\
\text { witl } \\
\text { conv } \\
\text { be } \\
\text { conne }\end{array}$ & $\begin{array}{l}\text { eative } \\
\text { eyor } \\
\text { with } \\
\text { ctive } \\
\text { ers } \\
\text { out } \\
\text { eyor } \\
\text { lt } \\
\text { ctors }\end{array}$ & $\begin{array}{c}\text { Dissipative } \\
\text { conveyor } \\
\text { belt with } \\
\text { conductive } \\
\text { rollers, belt } \\
\text { connectors } \\
\text { permitted }\end{array}$ & $\begin{array}{c}\text { There } \\
\text { are no } \\
\text { special } \\
\text { require } \\
\text { ments }\end{array}$ & \multicolumn{3}{|c|}{$\begin{array}{l}\text { Dissipative conveyor belt with } \\
\text { conductive rollers, belt } \\
\text { connectors permitted }\end{array}$} & $\begin{array}{c}\text { There } \\
\text { are no } \\
\text { special } \\
\text { require } \\
\text { ments }\end{array}$ \\
\hline
\end{tabular}

The material of a transmission belt is considered to be dissipative if it meets the requirements of Table 6 with additional measures necessary according to the classification of hazardous areas [6].

Table 6. Requirements for transmission belts

\begin{tabular}{|c|c|c|c|c|c|c|c|c|c|}
\hline \multirow{2}{*}{$\begin{array}{c}\text { Belt } \\
\text { velocity }\end{array}$} & \multirow{2}{*}{$\begin{array}{c}\text { Dissipative } \\
\text { criteria }\end{array}$} & \multirow[t]{2}{*}{ Zone 0} & \multicolumn{2}{|r|}{ Zone 1} & \multirow[t]{2}{*}{ Zone 2} & \multicolumn{2}{|c|}{ Zone 20} & \multirow[t]{2}{*}{ Zone 21} & \multirow[t]{2}{*}{ Zone 22} \\
\hline & & & IIC & IIA \& IIB & & $\begin{array}{c}\text { MIE } \\
<10 \mathrm{~mJ}\end{array}$ & $\begin{array}{c}\text { MIE } \\
>10 \mathrm{~mJ}\end{array}$ & & \\
\hline$\leq 0,5 \mathrm{~m} / \mathrm{s}$ & \multirow[t]{3}{*}{$\begin{array}{l}(\mathrm{R} \times \mathrm{B}) / \mathrm{L} \\
\leq 600 \mathrm{k} \Omega\end{array}$} & \multicolumn{2}{|c|}{$\begin{array}{l}\text { Dissipative } \\
\text { transmission } \\
\text { belt with } \\
\text { conductive } \\
\text { rollers } \\
\text { without } \\
\text { transmission } \\
\text { belt } \\
\text { connectors }\end{array}$} & \multirow[t]{2}{*}{$\begin{array}{l}\text { Dissipative } \\
\text { transmission } \\
\text { belt with } \\
\text { conductive } \\
\text { rollers, } \\
\text { transmission } \\
\text { belt } \\
\text { connectors } \\
\text { permitted }\end{array}$} & \multirow{3}{*}{$\begin{array}{l}\text { There } \\
\text { are no } \\
\text { special } \\
\text { require } \\
\text { ments }\end{array}$} & \multirow{2}{*}{\multicolumn{3}{|c|}{$\begin{array}{l}\text { Dissipative transmission belt } \\
\text { with conductive rollers, } \\
\text { transmission belt connectors } \\
\text { permitted }\end{array}$}} & \multirow{3}{*}{$\begin{array}{l}\text { There are } \\
\text { no } \\
\text { special } \\
\text { requirem } \\
\text { ents }\end{array}$} \\
\hline $0,5-5 \mathrm{~m} / \mathrm{s}$ & & \multicolumn{2}{|c|}{$\begin{array}{c}\text { They are not } \\
\text { allowed }\end{array}$} & & & & & & \\
\hline $5-30 \mathrm{~m} / \mathrm{s}$ & & \multicolumn{2}{|c|}{$\begin{array}{c}\text { They are not } \\
\text { allowed }\end{array}$} & $\begin{array}{c}\text { Dissipative } \\
\text { transmission } \\
\text { belt with } \\
\text { conductive } \\
\text { rollers } \\
\text { without } \\
\text { transmission } \\
\text { belt } \\
\text { connectors }\end{array}$ & & $\begin{array}{l}\text { They are } \\
\text { not } \\
\text { allowed }\end{array}$ & \multicolumn{2}{|c|}{$\begin{array}{c}\text { Dissipative } \\
\text { transmission belt } \\
\text { with conductive } \\
\text { rollers without } \\
\text { transmission belt } \\
\text { connectors }\end{array}$} & \\
\hline
\end{tabular}

To reduce the ignition danger of explosive atmospheres by electrostatic discharge, in addition to complying with the applicable safety and health requirements, an important role he has the selection of technical equipment's that is based on the classification of hazardous Ex, generated by gases, vapors, flammable mists and/or combustible dusts in air, the groups and categories of equipment as defined in the ATEX Directive 2014/34/EU, to which are added the types of protection to explosion [7].

Unlike technical equipment's, for materials, their selection for use in areas with danger of potentially explosive atmospheres is based on their properties to provide protection against static hazardous electricity, taking into account environmental factors, the probability of occurrence of a charging mechanism and ignition sensitivity of the explosive atmosphere by electrostatic discharges [7].

Also, at reduce the ignition danger of explosive atmospheres by electrostatic discharges can also significantly contribute the training of workers in the work process (workers) in terms of explosion protection by ensuring that the participants in the work process have the necessary competence to conduct the activities in such areas with explosion danger. 


\section{Conclusions}

The electrification of materials and technical equipment's, used in Ex., areas, constitutes a risk, namely that of an explosion and/or fire, generated by the appearance of electrostatic discharges in the presence of an explosive atmosphere.

The risk of initiating explosive atmospheres is present when using the technical equipment's as a result of the occurrence and generation of ignition sources including static electricity, respectively electrostatic discharges, from their non-metallic parts or cases.

In order to avoid and/or reduce to an acceptable level of explosion risk, the technical equipment's must comply with the essential safety and health requirements regulated by Directive 2014/34 / EU (ATEX).

In the case of the materials use, that can be subjected to the electrification process, in order to ensure an adequate level of security against explosions in dangerous Ex., areas, a very important role is played by the selection of these materials, which must comply with the safety requirements regarding the prevention of ignition electrostatic sources, in addition to other protective measures such as ensuring ways of dissipating charges to the ground, neutralizing charges, high humidity.

The selection of materials and technical equipment's, respectively the competence of participants in the work process, which conduct the activities in areas with danger of potentially explosive atmospheres, can also significantly contribute to reducing the ignition danger of explosive atmospheres by electrostatic discharges.

Given the multitude of factors that influence the occurrence and discharge of dangerous electrostatic charges from the point of view of initiating explosive atmospheres, it is necessary to continue the research in this field in order to develop specific requirements for identifying these factors in the industrial sectors, taking into account the specific activity of these sectors, respectively, in order to establish and implement the appropriate methods and protection means for preventing the occurrence of an explosion and/or fire.

\section{References}

1. M. Paraian, Guidance for the assessment of installations and personal protection equipment regarding the explosion risk in areas with potentially explosive atmospheres, (INSEMEX publishing house, Petroșani, 2013)

2. Directive 2014/34/EU (2014)

3. F.A. Paun, S. Burian, A.M. Jurca, D. Gabor, L.A. Lupu, S.M. Radu, Proceedings of the 8th Edition Symposium SESAM 2017, II, 441-450 (2017)

4. Standard SR EN 1127-1 (2011)

5. Standard SR EN 60079-0 (2013)

6. Standard IEC 60079-32-1 (2013)

7. F.A. Păun, M. Părăian, A.M. Jurca, D. Gabor, N. Vătavu, C.M. Popa, Procedings of the 8th Internațional Multidisciplinary Scientific Symposium Universitaria SIMPRO 2018, 399-402 (2018) 